\title{
RESIDENTIAL SEGREGATION IN THE INDUSTRIALIZING CITY: A CLOSER LOOK ${ }^{1}$
}

\author{
Jason Gilliland ${ }^{2}$ \\ Department of Geography \\ The University of Western Ontario \\ London, Ontario, Canada \\ Sherry Olson \\ Department of Geography \\ McGill University \\ Montreal, Quebec, Canada
}

\begin{abstract}
This article maps and measures several dimensions of residential segregation in Montreal in 1881, thereby adding to our understanding of the social structure of the industrial city. Taking advantage of an unusual historical database-a historical geographic information system (H-GIS)—we locate 17,000 individual households with precision, and evaluate the "dissimilarity" of neighborhoods along several social dimensions and at various levels of spatial aggregation. The empirical findings suggest that Montreal was highly segregated along lines of ethnic identity as well as socioeconomic status; segregation values increased inversely with size of the spatial unit, but precision of unit boundaries have negligible effect. Coupling the highprecision GIS with a statistical model such as the classic index of dissimilarity lends new power to grasp the scale of phenomena, to inquire into behavioral choices of 19th-century households, and even to challenge our assumptions about the meaning of "segregation" or "integration."

[Key words: segregation, Montreal, historical-GIS.]
\end{abstract}

Were 19th-century industrial cities characterized by segregation or diversity? Were people separated to a greater extent by their ethnic identity or their social status? Despite recognition of the ethnic diversity of 19th-century cities of North America and their wide range of class differences, we have few ecological analyses. For the study of residential

\footnotetext{
${ }^{1}$ David S. Wong generously provided the segregation extension; and technical advice was provided by Kevin Henry and Rosa Orlandini. We are greatly indebted to fellow contributors to the MAP geodatabase project Montréal, l'avenir du passé: Rosalyn Trigger (University of Aberdeen), Jean-Claude Robert (UQÀM), and Robert Sweeny (Memorial University of Newfoundland). David Hanna (UQÀM), and Robert Lewis (University of Toronto) were long involved in tests of rental values and construction of street segments. Key geodatabases and financial support for MAP were provided by the City of Montréal, Bibliothèque national du Québec, the Network Centre of Excellence in Geomatics (GEOIDE), the Centre interuniversitaire d'études québécoises (CIEQ) at Laval and Trois-Rivières, and the Social Sciences and Humanities Research Council of Canada (SSHRC). Record-matching was carried out by Sherry Olson with Patricia Thornton (Concordia University) and Danielle Gauvreau (Concordia University) for demographic analyses funded by SSHRC. Jason Gilliland received vital research support for the creation and extension of the H-GIS from SSHRC and the University of Western Ontario Academic Development Fund.

${ }^{2}$ Correspondence concerning this article should be addressed to Jason Gilliland, Department of Geography, University of Western Ontario, London, Ontario N6A 5C2, Canada; telephone: 519-661-2111 ext. 81239; email: jgillila@uwo.ca
} 
segregation in a 19th-century industrial city, Montreal makes a convenient laboratory; by 1880, it was the largest city in Canada, with 175,000 residents, comparable to Boston or Baltimore. The primary aim of this study is to map and measure the several dimensions of residential segregation in Montreal in 1880, thereby adding to our understanding of its sociospatial structure. Taking advantage of an unusual historical database-a historical geographic information system (H-GIS) - we locate 17,000 individual households with precision, and evaluate the "similarity" or "dissimilarity" of neighborhoods along several social dimensions and at various levels of spatial aggregation. This article also aims to address the problems of scale and boundaries, which have made it so difficult to compare levels of segregation in cities past and present.

Following a brief review of the problem of interpreting segregation in a fast-growing city, we provide a brief survey of Montreal in 1880 to introduce the issues we want to examine, particularly the problem of scale of analysis (see Massey and Denton, 1988; and Wong et al., 1999, 2007, for discussion of methodological issues). We employ individual and household-level data from censuses, tax rolls, and city directories to locate each family on one of 10,000 building lots. Such locational precision allows us to experiment with reaggregation of the data into spatial units of any chosen scale, thereby isolating the distinct problems of scale and boundaries. In the third section of the article we report the measurements compiled using David Wong's convenient GIS-based tool to calculate a standard index of segregation (or "dissimilarity"). Then, at greater length, we consider the interplay among several dimensions of ethnicity (language, religion, and national origin), and between ethnicity and dimensions of purchasing power (occupational status and a rental assessment of occupied dwellings). Consistent results support the validity of the dissimilarity index and suggest that boundary problems are a minor obstacle to comparative analysis, although comparisons require firm control of scale. As we shall see, the observed levels of separation between groups varied systematically with the scale of the spatial units of observation. This is not a mere statistical artifact: in Montreal, the several social dimensions of diversity were "lived" at different scales. Separateness of various kinds was generated within a hierarchy of spaces and maintained through a variety of mechanisms. Historians were first attracted to GIS for map display and data management facilities (on H-GIS, see Gregory et al., 2001; Knowles, 2002, 2005; Gregory and Healey, 2007). But as urban geographers we can go much further: coupling H-GIS with a statistical model as simple as the index of dissimilarity lends new power to grasp the scale of phenomena, inquire into behavioral choices of 19th-century households, and even challenge our assumptions about the meaning of "segregation" or "integration."

\section{ASSESSING SEGREGATION IN THE 19TH-CENTURY CITY}

Despite recognition of the class and ethnic differences in 19th-century North American cities, we have few detailed ecological analyses of their social patterning. Classics of U.S. and Canadian history describe the early industrial city as less segregated than today: "social and economic heterogeneity was the hallmark of the age" (Warner, 1968, p. 50). Describing Philadelphia in 1860, Warner writes that "most areas of the new big city were a jumble of occupations, classes, shops, homes, immigrants, and native Americans" (1968, p. 50). Likewise, in his groundbreaking empirical study of urban ecology, Goheen (1970) showed that Toronto in 1860 was also dominated by a central core that contained 
a heterogeneous jumble of land uses; however, by the 1870s, sectoral patterns of spatial organization were already beginning to emerge, with separate dimensions of economic and ethnic status. On the other hand, Greenberg (1981) asserted that in Philadelphia in 1880, concentration of large contingents of any ethnic group into homogeneous areas did not yet exist. In contrast, Zunz (1982) reported that Detroit was already strongly segregated along ethnic lines, and, as automobile manufacturing transformed the city, ethnic segregation gradually gave way to income segregation by the first quarter of the 20th century as a new class consciousness permeated the multiethnic city (Zunz, 1982). As for Canada, Hiebert (1991) noted that Winnipeg experienced a dramatic increase of ethnic segregation during the first quarter of the 20th century, while class-based residential segregation remained stable; in fact, growing ethnic identification and ethnic segregation may have accelerated the emergence of class consciousness.

Early observers of social life in the U.S. industrial metropolis (i.e., the "Chicago School" sociologists-Park et al., 1925; Wirth, 1928) shared a view that ethnic concentration in a given area was the product of the desire of group members to establish their own identifiable neighborhoods and benefit from relationships with others of the same religion or nationality; therefore, as a particular immigrant group was assimilated into the dominant society, it would become spatially integrated with the native population, and so-called "ghettos" would gradually disappear. Although this "assimilation" model is embedded in much of the current literature on segregation, competing views of underlying processes and outcomes persist. ${ }^{3}$ Pratt (1911), a contemporary of the early Chicago School sociologists, argued that high levels of immigrant segregation in New York City to the end of the 19th century were due to the spatial concentration of factory employment opportunities and the lack of housing choice among low-paid immigrants. Greenberg (1981) likewise attributed differences of residential distributions of "native Whites," Irish, and Germans in Philadelphia in 1880 to differences in their industrial participation and the location of manufacturing jobs. She concluded that industrial affiliation was the primary organizing factor for "community," and that ethnicity was secondary, except for the Black population, who were more likely to live near other Blacks than were Whites in the same industry. ${ }^{4}$ For Montreal, Lewis (1991) saw industrial location as the driving force behind residential segregation as early as 1860; occupational structures and social class were primary determinants of residential patterns, and both were shaped by the emerging patterns of industrial location.

Considerably more attention has been devoted to examining residential differentiation in 19th-century British cities than those in North America. Although most researchers have argued that Victorian cities such as Liverpool already exhibited significant levels of residential segregation by mid-century (e.g., Lawton and Pooley, 1976; Carter and Wheatley, 1980), others, such as David Ward (1975, 1980), have asserted that most English cities were characterized by a residential mixing of the population until the end of the century, as in Leeds where only the extremes of rich and poor showed any overt signs of segregation. Moreover, Ward (1980) argued that perceptions of Victorian writers about increasing segregation in the 19th century reflected the experience of a small

\footnotetext{
${ }^{3}$ For a comprehensive discussion of major explanatory frameworks, see Chung and Brown (2007).

${ }^{4}$ For more on the contemporary class versus culture debate, see Clark (2007) and Sims (1999).
} 
middle class that was not representative of the larger population. A significant problem in trying to interpret the conflicting evidence on segregation in 19th-century cities is methodological inconsistency from study to study; each uses its own method for classifying variables such as occupation, ethnicity, and social class, and data are examined at a variety of scales (see the discussion in Dennis, 1984, and Pooley, 1984). In his critical and comprehensive review of the geographical scholarship on English industrial cities, Dennis (1984) concluded that the Industrial Revolution intensified segregation by social class over the course of the 19th century, but levels were likely not as high as in modern cities. With respect to ethnic segregation in 19th-century English cities, several researchers have identified high levels of segregation according to birthplace (Dennis, 1984). In cities such as mid-century Liverpool, with a high degree of ethnic diversity, the Irish-born were highly segregated from native-born residents; however, levels of Irish segregation declined over time, reflecting a cessation of migration after the famine (Pooley, 1977). Dennis (1984) concluded that "Overall, Irish segregation was more evident than the segregation of most occupational groups or skill levels within the working classes, but less obvious than the segregation of the upper middle classes" (p. 223).

Techniques introduced for study of 20th-century cities, such as social area analysis and factor analysis, dealt with the simultaneous presence of distinct patterns of segregation by income, age, race, ethnicity, and lifestyle (Johnston, 1976; Wong et al., 2007), but these techniques are not easily applied to available tabulations of 19th-century "raw material." Dennis (1984) warned about the difficulties of comparing dissimilarity index values and location quotients for historical cities of different sizes and at different levels of spatial aggregation. Variations in the sizes and types of urban settlements, as well as the scales at which individual-level data are aggregated and assessed, is likely a major source of differences between studies (Pooley, 1984). Even the most elaborate modern studies relied on data aggregated into administrative wards or tracts, and are cautious about making comparisons among cities or between censuses taken at different times with modified administrative boundaries (for recent comparative analyses, see Walks and Bourne, 2006; Johnston et al., 2007; and a rare historical exception by DeBats and Lethbridge, 2005). Sociologists undertaking temporal rather than spatial analyses have reported that differences of social status, notably the blue-collar/white-collar divide, were more rigidly constructed in Britain and yielded in the United States to a nuanced and continuous gradient of incomes. In North America, people appear to have interpreted success in terms of their income relative to that of their immediate neighbors, or relative to their own incomes a decade earlier. By evaluating their neighbors' achievements, they accepted their own status achievement in an expectation of lifetime mobility (e.g., Stouffer, 1949; Darroch and Ornstein, 1980, 1984).

Especially serious, and largely unrecognized in the literature, are issues surrounding scale: the appropriate scale of analysis, the meaning of segregation at a particular scale, and the interference or interplay of the several dimensions of segregation in a hierarchy of spaces and communities within a city. For such work, the published Canadian census is notoriously deficient. Its organization shows no historical memory trace: questions and definitions varied from one decade to the next, few cross-tabulations were published, and geographical organization was limited to the level of electoral districts (counties, municipalities, and townships), modified with each census (see critique in Curtis, 2000). Prior to 1901 no addresses were recorded, no tabulations published, or maps retained of the 
smaller divisions used for data collection within the city. Since the 1980s, patient accumulation of research efforts by historians, scholars in cognate disciplines, and volunteer genealogists, all armed with personal computers, now make it possible to reconstruct 19th-century urban ecologies by building digital databases from nominal census records and coupling these census records with other nominal sources such as city directories and tax rolls to provide street addresses. ${ }^{5}$

Accordingly, we explore the nature of residential segregation in Montreal by using the 1880 layers of a historical geographic information system (H-GIS) assembled by a team known as MAP, Montréal l'avenir du passé. ${ }^{6}$ The 1880 Montreal geobase integrates multiple sources of information on individuals and households compiled from nominal (census and tax roll) databases with layers of geographic features (buildings, lots, blocks, streets) digitized from a high-resolution atlas (Goad, 1881). Each layer is spatially referenced with precision (within a few meters) to common geographic coordinates (cadastral lots) for easy overlay, selection, and reaggregation, together providing an impressive representation of the social, economic, and physical environment of the city. In the following section, we use this multilayered GIS to provide an overview of Montreal in 1881 supported by maps of the distribution of various groups.

\section{What Do the Maps Suggest?}

Among North American cities of the late 19th century, Montreal offers a rare example of a strong Catholic majority (76\%) and an unusual linguistic split-63\% Frenchspeaking and $37 \%$ English-speaking. The pyramids in Figure 1 schematize the ethnic groups that made up $99 \%$ of the urban population in 1880 . British conquest had created a strong polarization between the French Canadian descendants of 17th-century pioneers and the descendants of Anglo-Protestants who arrived in increasing numbers from the early 19th century to 1850 . At the same time, Catholics arrived from Ireland, with massive entries in 1831,1847 , and 1849 . The cross-cutting nature of linguistic and religious affiliations placed the Irish Catholics in an unusual situation, sharing their language with the group at one pole, their religion with the other. As the nation's powerhouse of industrial development, Montreal contained enormous differences of wealth (Bradbury, 1993; Robert, 1994; Gilliland and Olson, 1998). The status pyramids of Figure 1, based on household rents, suggest that economic differences might reinforce the polarity of cultural differences. With high rates of natural increase and recurring waves of off-farm moves (notably 1871), the relative weights of subgroups, in terms of both population and purchasing power (Table 1), were subject to change, and tensions were expressed at all social boundaries.

\footnotetext{
${ }^{5}$ On the 1901 Canadian Families Project, see Buck et al. (2000); on 1881 census projects, see the International Microdata Access Group (www.prdh.umontreal.ca/imag), the North Atlantic Population Project (www.nappdata .org), and the Canadian Century Research Infrastructure (www.canada.uottawa.ca/ccri). These teams benefit from methodological innovations developed through the Integrated Public Use Microdata Series project (http:/ /www.ipums.umn.edu/)

${ }^{6}$ MAP includes layers for 1825, 1846, 1880, 1901, and 2000. To our knowledge, no other urban GIS compares in depth and scope (Gilliland and Olson, 2003; Sweeny and Olson, 2003).
} 
French Canadian

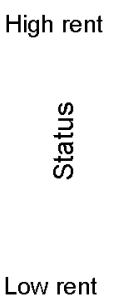

\section{A}

B

C

D

E

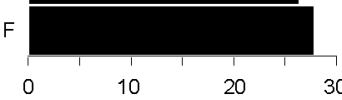

0

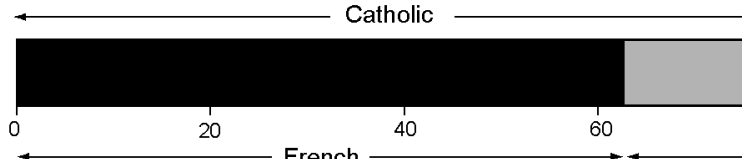

Percent of population (\%)
Irish Catholic
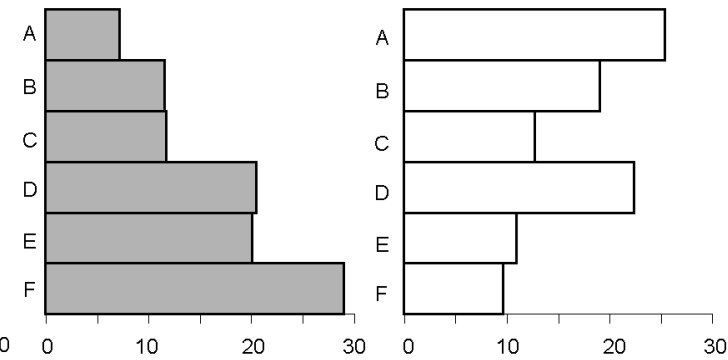

Protestant $\longrightarrow$

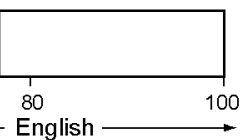

Fig. 1. Schematic of ethnicity and purchasing power in Montreal, 1881.

Despite the handicaps of cold print and shades of gray, let us exercise some imagination to conceive the high-density, high-diversity city of $1880 .{ }^{7}$ If households are displayed as points color-coded for ethnicity, they reveal decided concentrations of French Canadians in some areas, Protestants in others, and smaller concentrations of Irish Catholics. Zooming in for a closer look uncovers a finer-grained diversity. In the vicinity of St. Patrick's Church, just a few blocks away, we would encounter a mix of Irish Catholics and Irish Protestants, or a mix of Irish Protestants with co-religionists of Scottish or English origin. Within a single block, there were sometimes French-speakers as well as English-speakers, and one notices conspicuous examples of Protestant households on a Protestant-owned lot, or Catholic households on a Catholic-owned lot. If we survey the city at this scale, we find blocks with properties in solid Irish Catholic ownership (Griffintown), and a curious line of separation between French- and English-speaking Catholics along the back-line fences between shopfronts on Notre Dame Street and the factory and craft enterprises fronting on William Street.

To explore purchasing power, the same database will display the rents of individual households. Cruising the streets, point by point and lot by lot, we observe regularities on this dimension as well. But fault lines also emerge: a dramatic leap from $\$ 80$ a year (close to the median) as we turn onto a "carriage street" like Sherbrooke, with its rents of $\$ 250$, running as high as $\$ 800$. Within a two-block section, we discover the similarity of opposite block-faces (the street segment), a contrast between street-front and rear-of-the-lot dwellings (Olson and Hanna, 1990; Carey, 2002).

If we aggregate the 28,000 rental values into street segments (or twin block-faces), we can zoom out again to observe the pattern of median rents: a patchwork of 370 street

\footnotetext{
${ }^{7}$ See full-color examples at http://geography.ssc.uwo.ca/faculty/gilliland/segregation.htm
} 
TABle 1. SAMPle Sizes and Matching Rates, Montreal 1881

\begin{tabular}{|c|c|c|c|c|c|c|}
\hline \multicolumn{7}{|c|}{ Households by rental classes } \\
\hline & \multirow{2}{*}{$\begin{array}{l}\text { Dwelling rent } \\
\$ / \text { year }\end{array}$} & \multicolumn{2}{|c|}{ All taxroll households } & \multicolumn{2}{|c|}{ Matched set } & \multirow{2}{*}{$\begin{array}{l}\text { Percentage matched } \\
\text { of enrolled households }\end{array}$} \\
\hline & & $n$ & $\%$ & $n$ & $\%$ & \\
\hline A & $250-2,500$ & 1,894 & 7.1 & 1,424 & 8.0 & 75.2 \\
\hline B & $90-249$ & 5,807 & 21.7 & 4,208 & 23.7 & 72.5 \\
\hline $\mathrm{C}$ & $60-89$ & 5,963 & 22.3 & 3,960 & 22.3 & 66.4 \\
\hline $\mathrm{D}$ & $10-59$ & 13,045 & 48.8 & 8,147 & 45.9 & 62.5 \\
\hline \multicolumn{2}{|c|}{ Sum } & 26,709 & 100.0 & 17,739 & 100.0 & 66.4 \\
\hline \multicolumn{2}{|c|}{ Vacant or unspecified } & 4,407 & & 252 & & \\
\hline
\end{tabular}

Households by occupational status

\begin{tabular}{|c|c|c|c|c|c|c|}
\hline & \multirow{2}{*}{$\begin{array}{c}\text { Occupational } \\
\text { status }^{\mathrm{a}}\end{array}$} & \multicolumn{2}{|c|}{ All taxroll occupants } & \multicolumn{2}{|c|}{ Matched set } & \multirow{2}{*}{$\begin{array}{l}\text { Percentage matched } \\
\text { of enrolled households }\end{array}$} \\
\hline & & $n$ & $\%$ & $n$ & $\%$ & \\
\hline 1 & High & 6,458 & 27.3 & 4,470 & 28.0 & 69.2 \\
\hline 2 & Middle & 11,911 & 50.3 & 8,016 & 50.2 & 67.3 \\
\hline 3 & Low & 5,319 & 22.5 & 3,484 & 33.3 & 65.5 \\
\hline \multicolumn{2}{|c|}{ Sum } & 23,688 & 100.0 & 15,970 & 100.0 & 67.4 \\
\hline \multicolumn{2}{|c|}{ Others unspecified } & 7,428 & & 2,021 & & \\
\hline
\end{tabular}

Households by ethnic categories

\begin{tabular}{|c|c|c|c|c|c|c|c|}
\hline \multirow[b]{2}{*}{ Category $^{\mathrm{b}}$} & \multicolumn{2}{|c|}{ All census families } & \multicolumn{2}{|c|}{ Matched set } & \multirow{2}{*}{$\begin{array}{c}\text { Percentage } \\
\text { matched }\end{array}$} & \multicolumn{2}{|c|}{ Suburban families } \\
\hline & $n$ & col. $\%$ & $n$ & col. $\%$ & & $n$ & col. $\%$ \\
\hline French Catholic & 15,632 & 55.8 & 9,473 & 52.9 & 60.6 & 5,232 & 76.8 \\
\hline Irish Catholic & 4,977 & 17.8 & 3,296 & 18.4 & 66.2 & 668 & 9.8 \\
\hline Protestant & 7,411 & 26.4 & 5,150 & 28.7 & 69.5 & 916 & 13.4 \\
\hline Sum of three groups & 28,020 & 100.0 & 17,919 & 100.0 & 64.0 & 6,830 & 100.0 \\
\hline Others & 228 & & 145 & & 63.6 & & \\
\hline
\end{tabular}

${ }^{a}$ Occupational status is based on ranking of median rents of householders of 80 occupations: 1 = merchants and professionals (categories A and B in Fig. 1); 2 = skilled, semiskilled, and clerks (C and D in Fig. 1); 3 = laborers, carters, "unskilled" (E and F in Fig. 1); the unspecified are primarily widows and retired "gentlemen."

${ }^{\mathrm{b}} 5.5 \%$ of households, of mixed ethnicity, were classed by husband's affiliation. Other groups, amounting to $<1 \%$, were excluded from calculations.

Sources: Municipal taxroll of June 1880, and nominal census of April 1881, Montreal (city limits).

segments resolves into rather broad patterns, with a powerful concentration of high rents on the terraces rising toward Mount Royal. The bulk of high-rent households were situated between the Dorchester Street terrace (now Boulevard René-Lévesque) at about 35 feet elevation, and the Sherbrooke Street terrace at about 50 feet elevation. In fact, 1880 
was the moment when status was most strongly correlated with elevation $\left(r^{2}=.38\right)$. Highrent housing was associated with larger dwellings, fashion-conscious architecture, wider streets, and more reliable municipal services, as well as topographic advantages of drainage, winter sunshine, summer breezes, view, and visibility.

The 19th-century "walking city" was built at high densities, and in the Atlantic seaports of North America, as in British and European cities, even wealthy people lived in terraces of row housing (see Olson, 1997, on Baltimore). They occupied larger lots than working-class families, and, as we would expect from the status pyramids, the dimensions of ethnicity and purchasing power were not wholly independent factors in the allocation of urban residential space. The most intensive concentration of Protestant Montrealers was the high-rent district, already known in 1880 as "the golden square mile."

These observations at various map scales call for a more systematic treatment of scale. In measuring residential segregation, what is the appropriate scale of analysis? What effect does scale of observation have on our interpretation? If we aggregate household data to the crude level of wards used in municipal reports and the published tables of the Census of Canada, the city would appear as simple in its spatial layout as the schematic of Figure 1: an English-speaking city to the west, a French-speaking city to the east, divided along St. Lawrence "Main" Street (Fig. 2). The image had electoral implications and stubbornly persists to this day in the popular imagination. If we look at it by religion, we would again conceive a Protestant western half and a Catholic eastern half (Fig. 2) a division that for some readers may evoke images of modern Belfast's Shankill Road (Jones, 1965; Boal, 2002). But the moment we disaggregate to the 67 districts employed by the census-takers, the picture becomes more nuanced, and there emerge on the west side distinct zones of Catholic residents, in one case of Irish origin, and French origin in another.

We have introduced the key issues: the effects of scale and boundaries on our understanding of segregation, and the complicating role of several social dimensions such as language, religion, national origin, and purchasing power. In 1880 Montreal, residential segregation was meaningful only if interpreted in several social dimensions and at several levels of spatial aggregation. We will therefore experiment with measurement along two dimensions: a composite ethnicity based on religious and linguistic affiliation of the household ${ }^{8}$ and a socioeconomic status based on household rents. ${ }^{9}$ To tackle the issue of scale, we apply a single measure of dissimilarity at various levels of spatial aggregation: the city block, census division, or municipal ward. And to deal with the question of the "modifiable areal unit problem" (MAUP; Openshaw, 1984), we apply the

\footnotetext{
${ }^{8}$ Composite ethnicity is based on the cross-tabulation of religious and linguistic affiliations, with some debatable terminology. "Irish Catholic" includes small numbers of English-speaking Catholics of English, Scottish, and U.S. origins. The attempt to distinguish Irish Protestants from other Protestants extracted 630 households, but understates the Canadian-born; however, recent immigrants were most susceptible to segregated living and active roles in organizations such as the Orange Order (Senior, 1972). "Mixed marriage" households (8\%) were classified by ethnicity of husband on the grounds of the legal power assigned to him. Boardinghouses were classed by ethnicity of the operator couple. Institutions were excluded ( $3 \%$ of population).

${ }^{9}$ Occupational status categories are based on ranking median rents of occupations reported by household heads. Without rent data, it would be necessary to employ occupational status, and to compensate for titles such as widows and "gentlemen" by recourse to complementary sources.
} 

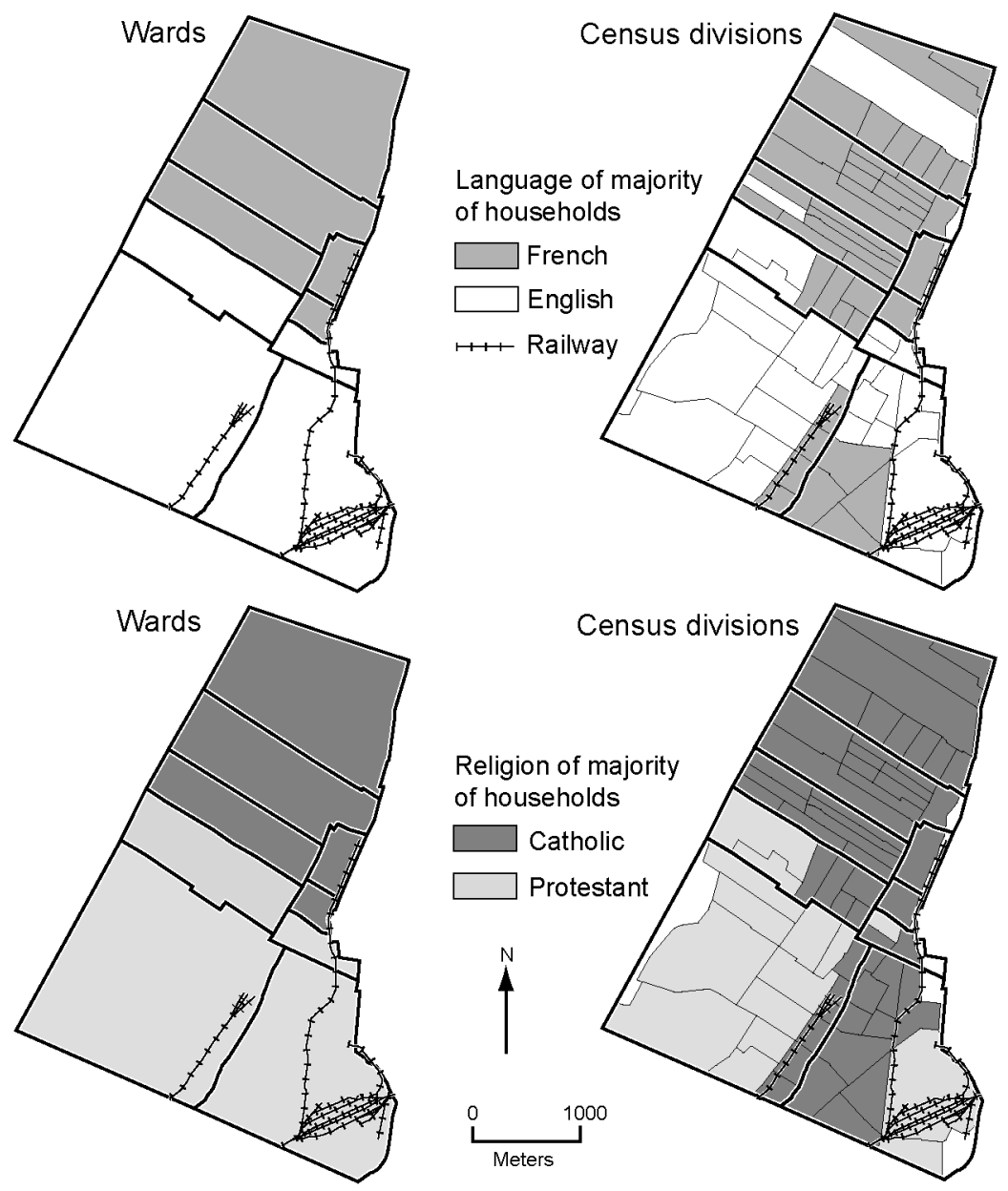

Fig. 2. Language and religion in Montreal in 1881 by ward and district.

measure to the data regrouped (or "binned") into a set of homogeneous boundaries (hexagonal grids) comparable in size to blocks, census divisions, and wards.

\section{What Do the Measurements Suggest?}

Before reporting the findings, let us clarify a few methodological details. Each analysis employs the same dataset, with variables from two sources; categories of ethnicity are derived from the census, whereas categories of socioeconomic status are from the municipal tax roll. Because all our computations of segregation are based on data for specific households, we are not disturbed by an "ecological fallacy" (Robinson, 1950).

The three "ethnic" aggregates, covering 99\% of the population, are composed from census variables reporting religion, language, country of birth, and a country of origin 
TABLe 2. LeVels of Spatial Aggregation EMPloyed

\begin{tabular}{lcrc}
\hline \hline & $\begin{array}{c}\text { Regions } \\
n\end{array}$ & $\begin{array}{c}\text { Households } \\
\text { mean } n\end{array}$ & $\begin{array}{c}\text { Area } \\
\text { mean ha }\end{array}$ \\
\hline Administrative ward & 9 & 3,457 & 164.6 \\
Census division & 67 & 471 & 20.8 \\
Street segment & 370 & 70 & 3.4 \\
City block & 942 & 33 & 1.1 \\
Hexagonal bins & & & \\
$\quad$ Size 1 (large) & 15 & 2,074 & 164.6 \\
Size 2 & 36 & 864 & 48.7 \\
Size 3 & 60 & 519 & 28.2 \\
Size 4 & 78 & 399 & 20.8 \\
Size 5 & 377 & 83 & 3.4 \\
Size 6 (small) & 992 & 31 & 1.1 \\
\hline
\end{tabular}

(paternal ancestry). Either the composite or any of the underlying variables can be displayed for the entire census population of individuals by 67 divisions, offering unprecedented opportunities for social analyses. ${ }^{10}$ To evaluate socioeconomic status, the Montreal tax roll identifies every property with a cadastral lot and provides for each dwelling on the property the name and occupation of the household head and an appraisal of its rental value on the market. ${ }^{11}$ Both an occupational status and an estimate of household purchasing power are therefore available, and these elements, too, can also be examined and displayed for the entire set of households within the city limits.

Matching of the two sources could only be carried out within the limits of the city of Montreal, and two-thirds of all households were successfully matched. ${ }^{12}$ A modest underrepresentation of the lowest-rent households (of the order of 5\%) results in a slight overrepresentation of Protestant households. ${ }^{13}$ Although one would prefer $100 \%$, the very large samples (over $60 \%$ of any district) provide dependable values; and the precision of MAP geocoding to the 10,000 lots of the city allows us to adopt any scale we choose for spatial analysis. We can further reaggregate the household points to any desired set of regions, and measures are reported for the levels shown in Figure 3 and Table 2: nine

\footnotetext{
${ }^{10}$ Divisions were inferred from the matches between tax roll owners and census householders.

${ }^{11}$ For the taxe locative we have verified the near-perfect correlation with floor area (Hanna and Olson, 1983), for 1901 a strong correlation with numbers of rooms (Gilliland and Olson, 1998), and, from an array of several thousand leases, its reliability as an estimator of actual rents paid.

${ }^{12}$ Failure to achieve a match results mainly from the following problems: (1) homonyms (sometimes father and son), (2) insufficient information for some widows, (3) the options of reporting a household in the name of the widow or her working son or brother, and (4) massive misspellings in data entry operations for the nominal census of 1881 . The problem of homonyms occurs more often among the Irish, who preferred a smaller range of prénoms (Margaret, Mary, and John); the other problems handicap the matching of French Canadians.

${ }^{13}$ Examination of median rents of street segments in the suburbs shows that their inclusion would produce a slight increase in absolute values of the segregation index throughout the tables.
} 

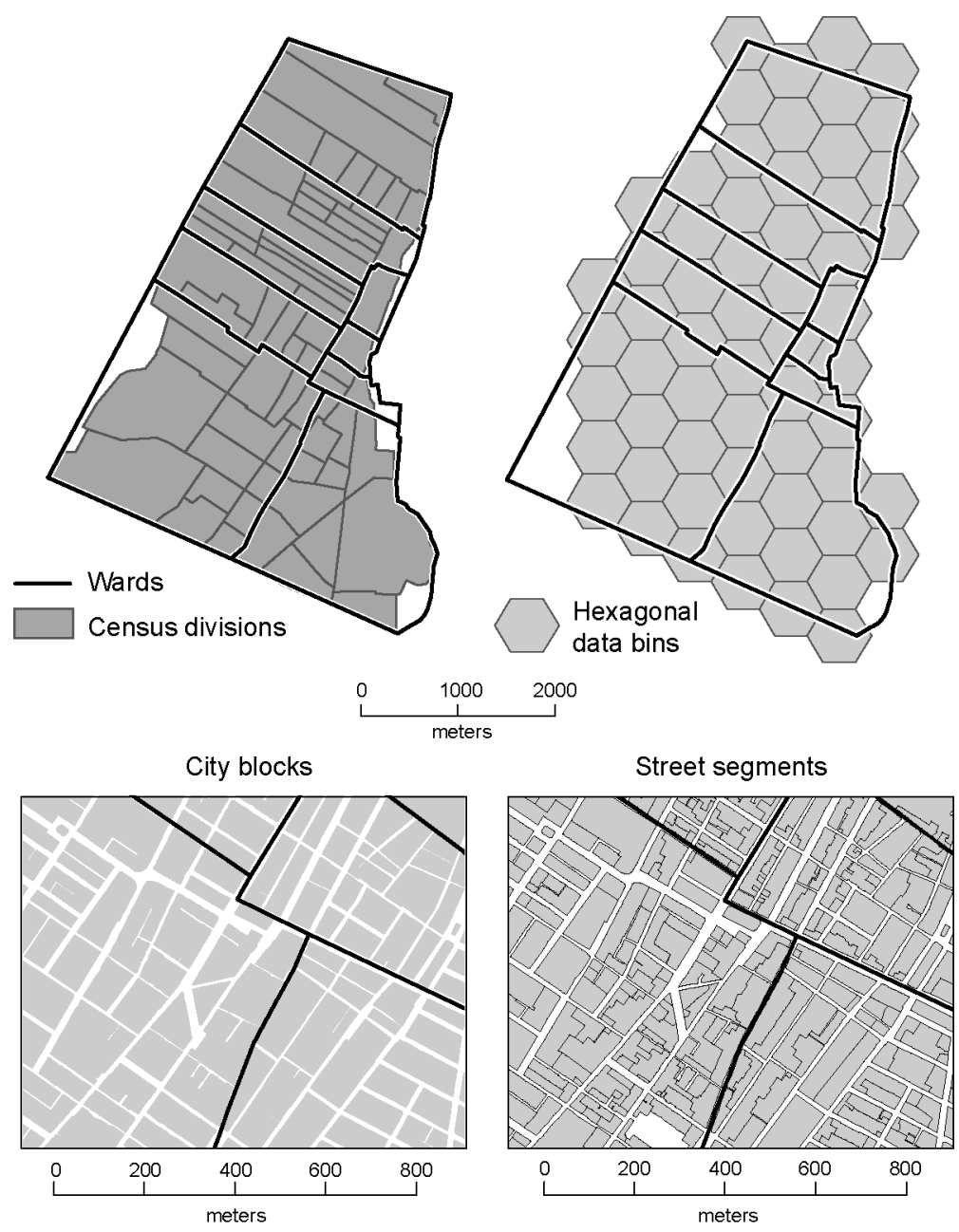

Fig. 3. Boundaries of spatial aggregation levels employed.

wards of the city, its 67 census divisions, its 370 "street segments" (Hanna and Olson, 1983, 1990), or its 942 city blocks. We can also apply uniform-shaped grids (hexagonal "bins") of sizes comparable to the wards, census divisions, or blocks, nested in Figure 3 to illustrate an array of scales. Binning the individual-level data into arbitrary grids provides an alternative view as well as an escape from any effect of irregular or ill-chosen political boundaries (Carter and Wheatley, 1980; Carr, 1991). The hexagon is, of course, the most effective shape with which to tessellate land masses and to bin data for visualization (Carr et al., 1992).

Within a database of 17,000 households ( 85,000 persons), selection by standard query language is essential. Individual points were aggregated by spatial joins, frequencies of households of each ethnicity (or each rent class) were compiled by query, and then the 
Wong segregation extension operates on the frequency tables to yield the index of dissimilarity measure:

$$
D=\frac{1}{2} \sum_{i=1}^{n}\left|\frac{e_{i}}{E_{T}}-\frac{f_{i}}{F_{T}}\right|
$$

where $n$ is the number of districts, $e_{i}$ is the English-speaking population of district $i, f_{i}$ is the French-speaking population of district $i, E_{T}$ is the total English-speaking population of the city, and $F_{T}$ the total French-speaking population.

Our interpretation focuses on the relative values, but to appreciate their absolute sizes it is reasonable to visualize the segregation index as the percentage of households of one group who would have to move in order for their distribution to approximate that of the other group. When one group is referred to another, for example Protestants to Irish Catholics, the measure is usually termed an index of dissimilarity $(D)$. When one group is compared with all others in the population, it is more often called an index of segregation $(S)$. We do both in this study. The index belongs to a broader family of measures of diversity widely used in plant and animal ecology (Duncan and Duncan, 1955; White, 1986; Massey and Denton, 1988; Wong et al., 2007).

Despite various modifications, users of the segregation index have long recognized constraints on its interpretation. Duncan and Duncan (1955) reported its sensitivity to the number and scale of spatial units. Geographers and some "spatial sociologists" have been concerned about the "aspatial" nature of the measure, its (lack of) treatment of unit boundaries and distances (Jakubs, 1981; Morgan, 1983; White, 1986; Massey and Denton, 1988; Morrill, 1991; Wong, 1993, 1997, 2002; Wong et al., 2007). Early critiques (Cortese et al., 1976; VanValey and Roof, 1976) also cautioned against using the index of dissimilarity for comparing metropolitan areas or estimating trends in cities that had been redistricted, a practice to be expected in fast-growing cities. Montreal, for example, doubled in size during the 20 years prior to 1880 and nearly tripled in the 20 years following. Because the segregation index is a binomial, it fosters polarity in thinking about identities: "race" as Black or White, native versus foreign-born, French-versus Englishspeaking, Catholic versus Protestant, or English-speaking Catholic versus all others. With a polarized instrument of measurement, we risk making assumptions about the independence of the variables; indeed, we know from studies of race and income in the United States, that these assumptions are misleading.

From previous studies of Montreal, we anticipated index values on the order of 35 for the Anglo-Protestant community versus the French Canadian (at the poles of our schema of "difference"), and something comparable for the highest rent class relative to the lowest, with smaller values for Irish Catholics in relation to their "nearness" along the lines of the schematic (Lewis, 1991). The key findings are displayed in Table 3, for the three cultural communities, four rent levels, and three levels of occupational status-each at four levels of spatial aggregation. We can track the progressive increase of the index values as we move from coarser- to finer-grained spatial units. At any level of spatial aggregation, the "middle" group of Irish Catholics shows less separation from both Protestants and French Canadians, but these values, too, run higher in the finer-grained analyses. In other words, the usual crude aggregation by municipal wards coarsens the 
TABle 3. Residential SEgREgation AT Four LeVEls of SPATIAL AgGREGATION, MONTREAL, 1881

\begin{tabular}{|c|c|c|c|c|c|c|c|c|c|}
\hline \multicolumn{3}{|c|}{ By ethnicity } & \multicolumn{3}{|c|}{ By occupational status } & \multicolumn{4}{|c|}{ By rent class } \\
\hline & & & 1 & 2 & 3 & $\mathrm{~A}$ & & & $\mathrm{D}$ \\
\hline $\mathrm{Fc}$ & Ic & $\operatorname{Pr}$ & High & Middle & Low & High & B & $\mathrm{C}$ & Low \\
\hline
\end{tabular}

By ward $(n=9)$

\begin{tabular}{|c|c|c|c|c|c|c|c|c|c|c|c|}
\hline & & & & & & & A & - & & & \\
\hline $\mathrm{Fc}$ & & & 1 & - & & & B & 43 & - & & \\
\hline 51 & - & & 2 & 25 & - & & $\mathrm{C}$ & 58 & 26 & - & \\
\hline 53 & 30 & - & 3 & 45 & 20 & - & $\mathrm{D}$ & 73 & 50 & 24 & - \\
\hline All & 39 & 42 & All & 31 & 8 & 29 & All & 60 & 35 & 11 & 42 \\
\hline
\end{tabular}

By census division $(n=67)$

\begin{tabular}{|c|c|c|c|c|c|c|c|c|c|c|c|c|}
\hline & & & & & & & & A & - & & & \\
\hline $\mathrm{Fc}$ & - & & & 1 & - & & & B & 61 & - & & \\
\hline Ic & 58 & - & & 2 & 39 & - & & $\mathrm{C}$ & 80 & 37 & - & \\
\hline $\operatorname{Pr}$ & 63 & 43 & - & 3 & 55 & 24 & - & $\mathrm{D}$ & 86 & 60 & 33 & - \\
\hline All & 58 & 44 & 52 & All & 43 & 21 & 25 & All & 76 & 45 & 26 & 48 \\
\hline
\end{tabular}

By street segment $(n=370)$

\begin{tabular}{|c|c|c|c|c|c|c|c|c|c|c|c|c|}
\hline & & & & & & & & A & - & & & \\
\hline $\mathrm{Fc}$ & - & & & 1 & - & & & B & 76 & - & & \\
\hline Ic & 66 & - & & 2 & 48 & - & & $\mathrm{C}$ & 93 & 52 & - & \\
\hline $\operatorname{Pr}$ & 70 & 52 & - & 3 & 65 & 30 & - & $\mathrm{D}$ & 96 & 71 & 43 & - \\
\hline All & 67 & 54 & 60 & All & 65 & 25 & 41 & All & 87 & 58 & 39 & 58 \\
\hline
\end{tabular}

By city block $(n=942)$

\begin{tabular}{|c|c|c|c|c|c|c|c|c|c|c|c|c|}
\hline & & & & & & & & A & - & & & \\
\hline $\mathrm{Fc}$ & - & & & 1 & - & & & B & 75 & - & & \\
\hline Ic & 69 & - & & 2 & 49 & - & & $\mathrm{C}$ & 92 & 53 & - & \\
\hline $\operatorname{Pr}$ & 73 & 55 & - & 3 & 66 & 34 & - & $\mathrm{D}$ & 95 & 71 & 44 & - \\
\hline All & 69 & 58 & 63 & All & 53 & 30 & 43 & All & 87 & 60 & 41 & 58 \\
\hline
\end{tabular}

appraisal, blurs the pattern, and underestimates the extent to which ethnic communities were residentially separated. With respect to purchasing power (section b), aggregation by census divisions captures only the extremes of "difference," whereas a finer aggregation, at the level of street segments, uncovers greater variation. Substantial differences of occupational status emerge vividly in the finest-grained picture, at the street segment or block level.

Using hexagons of mean size comparable to the census divisions, we obtained $D$ values closely resembling those for the census divisions on all three social dimensions: ethnicity, rents, and occupational status (Table 4). This finding suggests that we need not worry about refinement of "natural" boundaries or the comparability of census tracts in 
Table 4. Dissimilarity IndeX, Census Divisions, and HeXagons COMPared

\begin{tabular}{|c|c|c|c|c|c|c|c|c|c|c|c|c|}
\hline & $\mathrm{Fc}$ & Ic & $\operatorname{Pr}$ & & $\begin{array}{c}1 \\
\text { High }\end{array}$ & $\begin{array}{c}2 \\
\text { Middle }\end{array}$ & $\begin{array}{c}3 \\
\text { Low }\end{array}$ & & $\begin{array}{c}\text { A } \\
\text { High }\end{array}$ & B & $\mathrm{C}$ & $\begin{array}{c}\mathrm{D} \\
\text { Low }\end{array}$ \\
\hline \multicolumn{13}{|c|}{ By census division $(n=67)$} \\
\hline & & & & & & & & A & - & & & \\
\hline $\mathrm{Fc}$ & - & & & 1 & - & & & B & 61 & - & & \\
\hline Ic & 58 & - & & 2 & 39 & - & & $\mathrm{C}$ & 80 & 37 & - & \\
\hline $\operatorname{Pr}$ & 63 & 43 & - & 3 & 55 & 24 & - & $\mathrm{D}$ & 86 & 60 & 33 & - \\
\hline All & 58 & 44 & 52 & All & 43 & 21 & 25 & All & 76 & 45 & 26 & 48 \\
\hline \multicolumn{13}{|c|}{ By hexagons $(n=60)$} \\
\hline & & & & & & & & A & - & & & \\
\hline $\mathrm{Fc}$ & - & & & 1 & - & & & $\mathrm{B}$ & 57 & - & & \\
\hline Ic & 56 & - & & 2 & 35 & - & & $\mathrm{C}$ & 74 & 35 & - & \\
\hline $\operatorname{Pr}$ & 62 & 42 & - & 3 & 51 & 23 & - & $\mathrm{D}$ & 81 & 55 & 31 & - \\
\hline All & 59 & 36 & 52 & All & 39 & 18 & 32 & All & 66 & 32 & 19 & 25 \\
\hline
\end{tabular}

Table 5. Response of Segregation Index to Unit of AREa Measured ${ }^{a}$

\begin{tabular}{llllllll}
\hline \hline Hexagon size & A & B & C & D & E & F & G \\
\hline Large 1 & 53 & 42 & 52 & 30 & 53 & 33 & 61 \\
2 & 56 & 48 & 52 & 39 & 59 & 46 & 67 \\
3 & 59 & 51 & 56 & 41 & 62 & 46 & 71 \\
4 & 62 & 55 & 60 & 43 & 66 & 46 & 77 \\
5 & 67 & 60 & 65 & 49 & 69 & 54 & 83 \\
Small 6 & 69 & 62 & 69 & 55 & 72 & 46 & 76 \\
\hline
\end{tabular}

${ }^{\mathrm{a}}$ Whatever social dimension we evaluate, segregation is greater, and SI values larger, for smaller hexagons (sizes 5 and 6, as described in Table 2). Displayed are SI degrees of separation: (A) between language groups (English and French); (B) between religious groups (Catholic and Protestant); between any two of the communities of origin discussed (C) French and Irish Catholic, (D) Irish and Protestant, (E) Protestant and French; (F) between the richer half and the poorer half of all households; or, more extreme, (G) between the very rich (top 7\%) and all other households.

various metropolitan areas. Having confirmed the limited effects of boundary refinement and the significant effects of scale, we sought to formalize the effect of scale by creating an array of six sets of hexagonal bins, ranging in size from the equivalent of a municipal ward (mean of 1,645,000 $\mathrm{m}^{2}$ ) down to the equivalent of a city block (mean of 11,300 $\mathrm{m}^{2}$ ). The results in Table 5 show that the index for ethnicity intensifies to a maximum at the scale of the city block, while the street segment is optimal for revealing differences of purchasing power. 
TAble 6. Segregation By Both Ethnicity and PurChasing POWER ${ }^{\mathrm{a}}$

\begin{tabular}{|c|c|c|c|c|c|c|c|c|c|c|c|c|}
\hline & Fc-A & Fc-B & $\mathrm{Fc}-\mathrm{C}$ & Fc-D & Ic-A & Ic-B & Ic-C & Ic-D & Pr-A & Pr-B & Pr-C & Pr-D \\
\hline $\mathrm{Fc}-\mathrm{A}$ & - & & & & & & & & & & & \\
\hline $\mathrm{Fc}-\mathrm{B}$ & 28 & - & & & & & & & & & & \\
\hline $\mathrm{Fc}-\mathrm{C}$ & 47 & 29 & - & & & & & & & & & \\
\hline Fc-D & 71 & 51 & 32 & - & & & & & & & & \\
\hline Ic-A & 62 & 77 & 81 & 87 & - & & & & & & & \\
\hline Ic-B & 49 & 46 & 58 & 69 & 48 & - & & & & & & \\
\hline Ic-C & 60 & 51 & 51 & 61 & 62 & 37 & - & & & & & \\
\hline Ic-D & 76 & 69 & 62 & 65 & 79 & 63 & 36 & - & & & & \\
\hline Pr-A & 75 & 91 & 92 & 94 & 32 & 72 & 81 & 88 & - & & & \\
\hline Pr-B & 53 & 59 & 61 & 72 & 43 & 32 & 49 & 70 & 52 & - & & \\
\hline Pr-C & 60 & 50 & 50 & 60 & 70 & 41 & 27 & 49 & 83 & 42 & - & \\
\hline Pr-D & 71 & 62 & 55 & 59 & 75 & 55 & 31 & 33 & 88 & 59 & 27 & - \\
\hline All & 50 & 42 & 30 & 35 & 64 & 41 & 36 & 50 & 78 & 46 & 36 & 40 \\
\hline
\end{tabular}

${ }^{a}$ Ethnicities: $\mathrm{Fc}=$ French Canadian; Ic = Irish Catholic; $\mathrm{Pr}=$ Protestant. Rent groups: A (high) to D (low; see Table 2 for annual values).

To evaluate the interactions of the dimensions of ethnicity and purchasing power, we undertook two additional analytical steps. Using the set of 60 hexagons at the scale of census divisions, for which we obtained strong variation on both dimensions, we generated the frequencies of 12 subpopulations cross-tabulated by both ethnicity and economic status (rent class; Table 6). Here we note that all three high-rent populations (together amounting to $7 \%$ of the entire population) were strongly segregated from low-rent populations of the same ethnicity, and the effect was more intense in the two Englishspeaking groups. The $D$ value between high-rent and low-rent French Canadians was 71, compared to $D=79$ between high- and low-rent Irish Catholics and $D=88$ between highand low-rent Protestants. The handful of high-rent Irish Catholic households were decidedly more integrated with high-rent Protestant households $(D=32)$ than with high-rent French Canadians $(D=62)$.

Then, to reduce the complexity, we subjected that matrix of dissimilarity index measures to multidimensional scaling (Cox and Cox, 1994; Stata v9, 2005). The twodimensional solution shown in Figure 4 portrays the relative social distances between groups as evidenced by their residential patterns. The display is easier to read than the large array of tables, and is statistically grounded. ${ }^{14}$ From this analysis, we inferred that residential arrangements reflected differences of purchasing power more accurately than differences of ethnicity, that the highest-rent populations were most isolated, and that the

\footnotetext{
${ }^{14}$ The two-dimensional solution obtained from SPSS procedure ALCAL accounts for $93.6 \%$ of variance in the original $12 \times 12$ matrix, with a Kruskal stress value of .13233 . This is an iterative search process to minimize "stress," a measure of departure of associations in the new matrix $(2 \times 12)$ from the associations in the original matrix (Kruskal and Wish, 1978; Cox and Cox, 1994).
} 


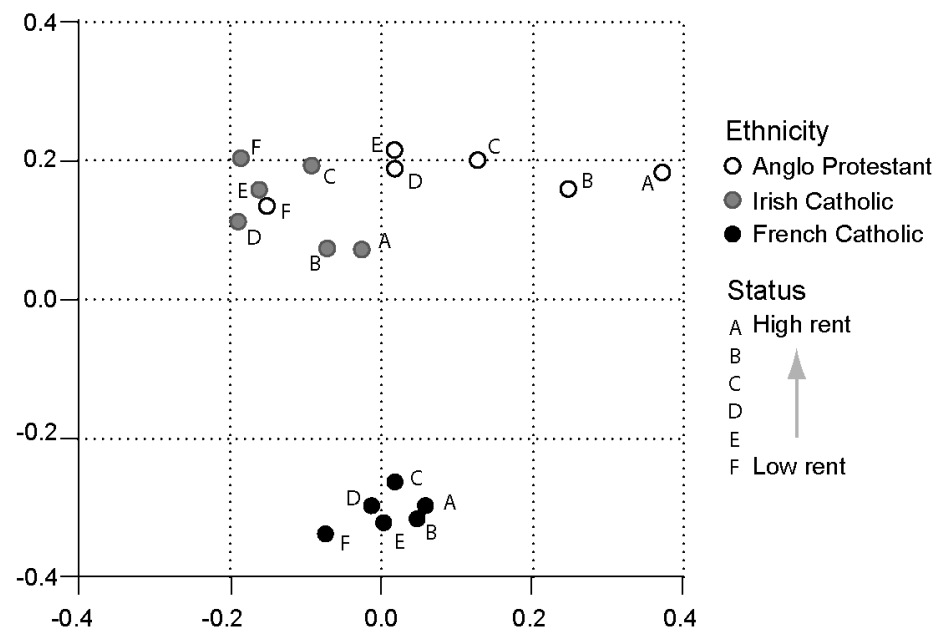

Fig. 4. Social distances between groups identified with multi-dimensional scaling.

gap between language groups was greater than between religious groups. The four Irish Catholic populations were consistently sandwiched in among the Protestants, tracking at each rent level, with a gulf between them and the French Canadian populations. Inclusion of an Irish Protestant subset (not shown) would place them between Irish Catholics and Other Protestants. Indeed, we might surmise that commonality of origin in Ireland was contributing to the integration of Irish Catholics into a broad Anglophone polity, as well as commonality of language, higher rates of mixed marriages, and perception of a shared minority status. This is what we inferred from the initial maps: the highest-rent Protestants, those with greatest "choice," were living in an exclusive zone, while low-rent Protestants with least choice were more scattered through an ethnically mixed belt. One might explore other "lower-middle" segments belonging to ethnic borderlands, notably Protestants of German origin, Catholics of German and Italian origin, and Jews of English and German origin. Forays of this kind suggest interference of the various categories, and perhaps a hierarchy of dimensions of identity.

\section{WHAT ARE THE PROCESSES DRIVING SEGREGATION?}

Because patterns of segregation based on particular social dimensions emerge at distinct map scales, suggesting that distinct mechanisms were involved, each pattern requires its own explanation. Residential location is shaped by the behavioral choices of households whose decisions are influenced by their budgets as well as such variables as stage in the life cycle, housing stock availability, household size, and journey to work (Gilliland, 1998; Kok et al., 2005). In addition to these factors, we have argued elsewhere that kinship also plays a role (Gilliland and Olson, 1998).

The Montreal situation raises some intriguing questions about the functionality of "segregation." What drew people, or pushed them, into flocking together according to particular social characteristics? How close together? In this discussion, we consider the 
spatial implications of the ethnic composition of households, demands of the extended family, patterns of property ownership, the institutionalization of cultural boundaries, and the organization of work in terms of language, hiring practices, and commuting patterns. We pursued experiments to test these factors for scale dependence, and discovered that each operated within a particular spatial range. With a household's choice of residence shaped by processes operating at different scales, our approach was to first examine the effects of the smallest radius, where we observed high levels of cultural homogeneity, and then work our way out to the processes of larger sweep that produce broader patterns of segregation.

One might consider the cornerstone of diversity to be the combination of ethnicities within the household itself. From the 1881 census, we know that one person in ten, within the city limits, was living in a household that included someone of another group (Irish Catholics more often than others). Diversity had quite a different meaning between husband and wife, between master and servant, or between boardinghouse keeper and boarders. Overall, $5 \%$ of marriages crossed the language barrier; about $2.5 \%$ crossed the religious barrier. Thus, the religious barrier to marriage was higher than the linguistic barrier, which we might expect from the institutional entrenchment, ${ }^{15}$ the discipline attempted by the clergy, and debates in the public press. Table 7 shows, however, that Irish Catholic women were much more likely than others to marry outside their group (20\%), and more likely to marry Protestant husbands, for some of them a step "up." In 1880, about one-fifth of all private households were keeping a servant ( 9 out of 10 were women), and two-fifths of Protestant households. Two-thirds of all live-in servants were of the same ethnicity as their employers. ${ }^{16}$ The incidence of a servant role and employment by "others" differed: female Protestant servants could always find employment in Protestant homes (96\%), while the majority of female Irish Catholic servants (70\%) had to go outside their own community into Protestant homes. Stereotypes were a part of the much-discussed market for servants, with advertising aimed at country girls and potential immigrants, the importation of children, and institutional practices of apprenticing orphans (Parr, 1994). Households usually selected lodgers of the same ethnicity (Baskerville, 1991; Harris, 1992), but centrally located boardinghouses were more cosmopolitan, catering to white-collar workers and the unmarried or widowed. High turnover among both servants and lodgers suggests that a large share of the population may have experienced these milieux of intercultural encounter for months or years.

The nuclear family is everywhere treated as the behavioral unit for studies of mobility, and, of the 1881 households of Montreal, $85 \%$ superficially appear to fit this notion. Close study of a sample for 1891 showed that at least one-third were in fact "re-composed" units, their membership reorganized in the course of a decade (Olson and Thornton, 2001). Nineteenth-century death rates induced frequent re-composition, to adapt to loss of the

\footnotetext{
${ }^{15}$ On the ways in which churches and prestigious institutions "anchored" the high-rent neighborhoods, see MacLeod (2003), MacLeod and Poutanen (2004), and Trigger (2001, 2002).

${ }^{16}$ This pattern was especially noticeable in 1842, when Irish Catholic youths were "exported" into service (Olson and Thornton, 2002), and persisted in 1861. By 1901, wealthier Protestants had obtained more Protestant servants of rural origins (Ontario and Quebec) or from recent immigrants from Britain.
} 
TABLE 7. ETHNiC COMPOSITION OF HOUSEHOLDS

\begin{tabular}{|c|c|c|c|c|c|c|c|}
\hline & \multicolumn{3}{|c|}{$\begin{array}{l}\text { Identity of the husband } \\
\text { (column \%) }\end{array}$} & \multicolumn{3}{|c|}{$\begin{array}{l}\text { Identity of the husband } \\
\text { (row \%) }\end{array}$} & \multirow{2}{*}{$\begin{array}{c}\text { All } \\
\text { households } \\
(n)\end{array}$} \\
\hline & $\begin{array}{c}\text { French } \\
\text { Canadian }\end{array}$ & $\begin{array}{c}\text { Irish } \\
\text { Catholic }\end{array}$ & Protestant & $\begin{array}{c}\text { French } \\
\text { Canadian }\end{array}$ & $\begin{array}{c}\text { Irish } \\
\text { Catholic }\end{array}$ & Protestant & \\
\hline \multicolumn{8}{|l|}{ Identity of the wife } \\
\hline French Canadian & 97.3 & 12 & 2.4 & 96.4 & 2.7 & 0.9 & 18,158 \\
\hline Irish Catholic & 2.4 & 85.2 & 6.4 & 9.7 & 80.5 & 9.7 & 4,377 \\
\hline Protestant & 0.3 & 2.8 & 91.2 & 0.9 & 1.8 & 97.2 & 6,279 \\
\hline \multirow[t]{3}{*}{ All households ( $n$ ) } & 17,987 & 4,136 & 6,691 & & & & \\
\hline & \multicolumn{3}{|c|}{$\begin{array}{l}\text { Identity of master/mistress } \\
\text { (column \%) }\end{array}$} & \multicolumn{3}{|c|}{$\begin{array}{l}\text { Identity of master or mistress } \\
\text { (row } \%)\end{array}$} & $\Delta 11$ \\
\hline & $\begin{array}{c}\text { French } \\
\text { Canadian }\end{array}$ & $\begin{array}{c}\text { Irish } \\
\text { Catholic }\end{array}$ & Protestant & $\begin{array}{c}\text { French } \\
\text { Canadian }\end{array}$ & $\begin{array}{c}\text { Irish } \\
\text { Catholic }\end{array}$ & Protestant & $\begin{array}{l}\text { servants } \\
\quad(n)\end{array}$ \\
\hline \multicolumn{8}{|l|}{ Identity of the servant } \\
\hline French Canadian & 95.2 & 16.6 & 10.3 & 80.6 & 4.5 & 14.9 & 2,027 \\
\hline Irish Catholic & 4.3 & 72.8 & 37.8 & 4.7 & 25.5 & 69.9 & 1,587 \\
\hline Protestant & 0.5 & 10.6 & 51.2 & 0.5 & 3.7 & 95.8 & 1,586 \\
\hline Sum of servants $(n)$ & 1,715 & 555 & 2,930 & & & & \\
\hline \multicolumn{8}{|l|}{ Households } \\
\hline With a servant $(n)$ & 1,701 & 530 & 2,901 & & & & \\
\hline As $\%$ of all households & 10.9 & 10.6 & 39.1 & & & & \\
\hline
\end{tabular}

Source: Nominal census of 1881, Montreal and suburbs.

prime "breadwinner" (Thornton and Olson, 1997; Gilliland, 1998; Gilliland and Olson, 1998).

Even when the group dwelling together remained stable, it was not independent of a wider circle of kin. Within this circle, based on the lifetime intensity of supportive, familial ties, social pressures were exerted, including hostility to cross-religious or cross-class marriages. Intense socialization of the extended family produced an overlapping of kinship and neighboring (e.g., Gilliland, 1998), so that cousinage was a major factor in the functioning of neighborhoods. The city's most common housing type was the twostory, upstairs-downstairs duplex, with the triple-decker becoming more common after 1880 (Hanna, 1986; Dufaux, 2000). We still appreciate today the mutual assistance between young mothers, or parents and grandparents, but it is harder to appreciate the importance in 1880 of the micromanagement of a yard shared by four or five households with its privies, woodsheds, and chicken coops. Thus extended families practiced microagglomeration in order to control a micro-milieu.

Within the framework of an annual lease, Montrealers moved often; as many as $20 \%$ may have moved every year (Gilliland, 1998), most of them about 1 May. In such a system, residential choices were adjusted at short intervals and reflect responses to 
TABLE 8. ETHNICITIES OF OWNERS AND OCCUPANTS ${ }^{\mathrm{a}}$

\begin{tabular}{|c|c|c|c|c|c|c|c|c|c|c|}
\hline \multirow[b]{2}{*}{ Owner } & \multicolumn{3}{|c|}{ Number of dwellings } & \multirow[b]{2}{*}{ Neutral } & \multirow[b]{2}{*}{ All } & \multicolumn{5}{|c|}{ Percentage of dwellings (column \%) } \\
\hline & French & Irish & Protestant & & & French & Irish & Protestant & Neutral & All \\
\hline \multicolumn{11}{|l|}{ Occupant } \\
\hline French & 4,256 & 464 & 924 & 706 & 6,350 & 75.4 & 24.4 & 28.5 & 66.9 & 53.6 \\
\hline Irish & 560 & 852 & 639 & 104 & 2,155 & 9.9 & 44.7 & 19.7 & 9.9 & 18.2 \\
\hline Protestant & 830 & 588 & 1,674 & 245 & 3,337 & 14.7 & 30.9 & 51.7 & 23.2 & 28.2 \\
\hline All $(n)$ & 5,646 & 1,904 & 3,237 & 1,055 & 11,842 & & & & & \\
\hline All (row \%) & 47.7 & 16.1 & 27.3 & 8.9 & 100.0 & 100.0 & 100.0 & 100.0 & 100.0 & 100.0 \\
\hline
\end{tabular}

${ }^{a}$ Table is based on the 11,842 dwellings for which we can identify ethnicity of both owner and occupant. The "neutral" panel embraced corporate owners such as building associations, railways, and a handful of "freethinkers." Excluded are 18 dwellings owned by French Protestants, 51 by other Catholics (Italian, German), 31 by Catholic institutions, 39 where owner's ethnicity is not specified; 100 where occupants were of another origin: Jewish, Italian, German, Catholic.

Sources: Tax roll of June 1880, Census of April 1881.

many factors. The evidence from a sample of kinship networks (about 300 families in 1880) suggests that households with very close ties located within short distances of each other, within a line of sight or an 8-year-old's five-minute dash (Gilliland, 1998; Olson, 2000; Olson and Thornton, 2001). A search process heavily dependent on word of mouth reinforced the extended family and its daily activity spaces: nearly one-fifth of all moves were within the same block or to an adjoining block (Gilliland, 1998). The high priority of these intricate kinship networks reinforced the micro-ethnic patterns we have observed. Within the constraints of the walk to work and the dash to grandma's, a family each year re-established its niche, searching for a better house, a more responsive landlord, a brighter exposure, a cheaper or larger dwelling.

How did the ownership of property affect such behavior? Initial examination of the maps of household ethnicity displayed against the religion of property owners suggested that the property owners might well be introducing a bias through selection of tenants. Application of a simple probability model confirms this observation. Using the same database as in the earlier analyses, we cross-tabulated the numbers of dwellings by ethnicity of property owner and occupant (Table 8). If the distribution was random, meeting the constraints of the number of dwelling units available and demanded by the several groups, each would rent to others in the proportions shown in the final column. In reality, much larger proportions of residents shared the ethnicity of the property owner. When the owner lived on the same lot, ethnic preference was about double what we would expect from a random process. Rates of owner occupancy did not differ markedly among the three cultural communities. If we remove from the pool dwellings occupied by their owners and dwellings on the same lot, the effect is modest: landlords still favored their own group.

The effect of owners' influence on the ethnicity of occupants was probably associated with inheritance and the subdivision of lots occupied by several heirs, and by a tendency 
of owners, strong in 1880, to concentrate their investment properties in their own neighborhood of residence. As a result, property ownership played a role in sustaining cultural segregation as well as creating concentrations by purchasing power. This was carried to an extreme in the development of the "square mile" (MacLeod, 2003). Stanley Bagg, for example, retained a ground-rent interest in the properties he sold and ensured high-rent residential construction through sales transactions that required three-story construction in brick or stone, and, on grounds of fire insurance rates, exclusion of industry. When he died in 1854, the will insisted that his heirs follow the same practice. The zoning informally exercised by owners like Bagg crystallized into a proposal in 1904 for a bylaw to exclude industrial and commercial uses from the ring of properties surrounding the highrent zone of 1880.

Modern studies pay attention to the journey-to-work constraint, and in the 19th century certain occupations or professions kept their members on very short tether-notably the long hours of barber, bartender, or hotel clerk; the erratic schedules of stevedores; the summer dawn-to-dark shift on construction sites; the on-demand assignments of railway train crews; and the on-call availability of policemen and firemen. No more than one quarter of the population could afford to commute by horsecar, and for perhaps half the population the constraint was a 15-or 20-minute walk, still a fairly large radius of 1.5 km. ${ }^{17}$ Ralph Hoskins' (1989) comparative geographical analysis of Francophone workers in the wood-working shops versus Anglophone workers in the metal shops of the Grand Trunk Railway, revealed the interplay of religion and occupation with respect to the residential patterning of the working-class district of Point Saint-Charles. Both groups resided within walking distance of the shops, and the neighborhood had a remarkably homogeneous slice of household purchasing power, low but not rock-bottom. Hiring was differentiated by religion and national origin, and the GTR, like other firms, gave preference to the son or nephew of a dependable employee (Hoskins, 1989). These sections of "the Point" were among the most ethnically segregated neighborhoods in Montreal, comparable to the "Golden Square Mile" and the solidly French-speaking industrial neighborhood of Saint-Henri. These three exhibited very different neighborhood economies, and the combination of ethnicity and socioeconomic status suggests that their concentrations by religion, language, industrial sector, and purchasing power were generated by distinct processes.

Can we obtain a more convincing picture of the impact of occupation on residential arrangements? Because some economic activities were concentrated in certain parts of Montreal, as shown by Lewis (2000), we selected five well-defined occupational groups whose median wage lay near the city's median, so that rental status is not a hallmark of their separation from one another. All of these workers had an interest in minimizing their journey to work because the horsecars were expensive and unreliable in winter. In Table 9 we estimate their degree of segregation from each other and from all workers. The construction trades (bricklayers, masons, and plasterers) show a relatively high value, and the maps display a distinctive peripheral pattern that reflects opportunities on a frontier of construction. In contrast, carters and drivers remained close to the docks, markets, and

\footnotetext{
${ }^{17}$ We arrived at the estimate by experiments with redistributing population into the nearest available housing by half-kilometer rings.
} 

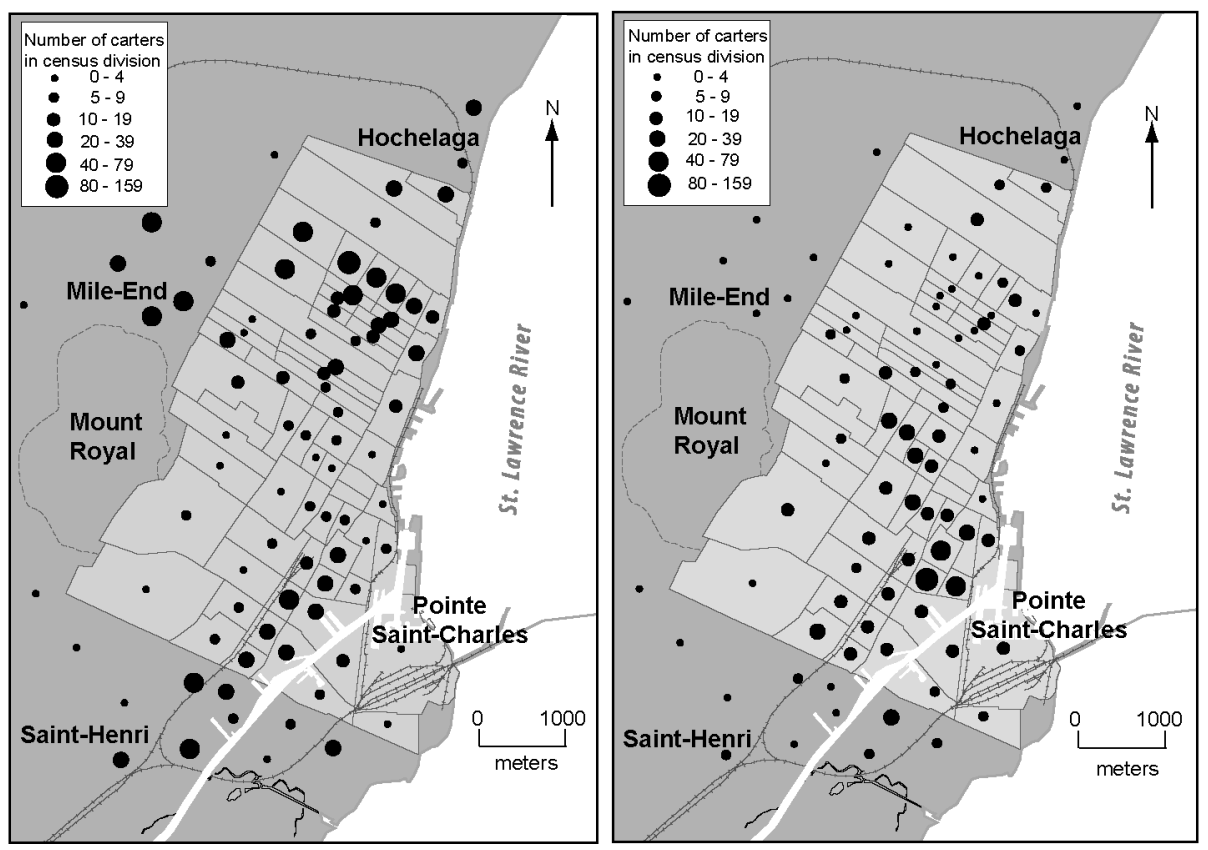

Fig. 5. Locations of homes of French (left) and English (right) carters in Montreal, 1881.

freight stations on the older and larger lots well adapted to stabling and turning around wagons. To be close to their customers, tavernkeepers, innkeepers, jewelers, milliners, barbers, musicians, and photographers were tied to central locations. Metalworkers also exhibited a relatively high index of segregation, reflecting the concentration of their jobs in industrialized western Montreal, as reported by Lewis (2000).

The highest segregation index values are reported for railway workers (brakemen, switchmen, and engineers), who mainly located within walking distance of the GTR (West) and CPR (East) railyards. In two cases - the carters and the metalworkers - the samples were large enough to test for differences between French- and English-speaking groups. In these instances, examination at the scale of wards ( 9 hexagons) showed little segregation between them, but at the block level substantial segregation was evident. We surmise that the journey-to-work constraint exerted its pull over a radius of 1-2 km, and within that range families exercised their identity preferences by choosing a particular street or clustering within extended families. For certain trades, there is reason to think that the location of French- or English-speaking entreprises reinforced the residential differentiation of their employees. Among carters and drivers, for example, Figure 5 shows a concentration to the north, heavily French Canadian, that reflects contracting from the stone quarries of Mile End. To the south, the Shedden monopoly of express cartage for the Grand Trunk Railway favored Irish carters, while the docks generated hauls from a mix of employers (Gilliland, 2004).

Mechanisms for sifting and sorting people in the city tended to heighten and entrench differentiation of experience, to favor an ideology of discrimination, shifting constantly 
TABLe 9. SegRegation of Household Heads BY LANGUAGE AND ECONOMIC SECTOR ${ }^{\mathrm{a}}$

\begin{tabular}{lcccccccccc}
\hline \hline & Build & Central $^{\mathrm{b}}$ & Carpenter & Hauling & Metal & Print & Rail & Shoe & Wood & All $^{\mathrm{c}}$ \\
\hline Building & - & & & & & & & & & \\
Central & 43 & - & & & & & & & & 29 \\
Carpenters & 29 & 39 & - & & & & & & & 28 \\
Hauling & 33 & 39 & 26 & - & & & & & & 24 \\
Metalworkers & 52 & 46 & 34 & 33 & - & & & & & 33 \\
Printing & 45 & 32 & 46 & 44 & 49 & - & & & \\
Railways & 56 & 52 & 46 & 48 & 30 & 53 & - & & 31 \\
Shoemaking & 29 & 37 & 25 & 29 & 49 & 44 & 57 & - & & 39 \\
Woodworking & 36 & 34 & 30 & 27 & 29 & 35 & 42 & 37 & - & 22 \\
English vs. & 68 & 50 & 58 & 63 & 58 & 61 & 55 & 56 & 63 & \\
French in & & & & & & & & & & \\
same sector & & & & & & & & & & \\
\hline
\end{tabular}

${ }^{a}$ Households are aggregated by census divisions $(n=84)$, Montreal and suburbs, 1881 .

b"Central" includes tavernkeepers, innkeepers, jewelers, milliners, musicians, and photographers.

c"All" shows extent to which the occupational group is segregated from all other census households.

between class and racialized interpretations. We can think of household decision-making as subject to a spatial hierarchy of controlling factors: the budget constraint confined the search to a large portion of the city outside the "Golden Square Mile." Given that range of opportunities, householders met the demands of occupation and minimized commuting distances. Within these middle-radius constraints, extended families sought to stick together, several couples making joint decisions and carving out a comfortable niche of cultural familiarity. In the aggregate, the journey-to-work constraints tended to integrate spaces of larger radius (the largest centered on the CBD and the docks), while kinship needs expressed themselves in the creation and perpetuation of ethnic nooks and crannies. All of these criteria had to be satisfied simultaneously. Within a city built for diversity, a competitive economy of increasing occupational diversity, and a complex ethnic-cultural structure based on both religious and linguistic diversity, a well-oiled legal system facilitated the year-to-year decision-making of households and the mutual adaptation of extended families to changes in circumstance.

The year 1880 was a particular moment in time, and the rapid pace of construction, as well as the concentration of employment in much larger workplaces, implies that household adaptation was becoming a more demanding process. The radius of the city was extending rapidly. Nonetheless, despite increases in residential density, the pressure of the journey to work could not be eased until the introduction of the electric streetcar in 1892.

To evaluate arguments that segregation may have increased over time, researchers have attempted to hold scale constant (e.g., Zunz, 1982; Buck, 2001). But this prevents us from assessing whether segregation was occurring at different scales. In Baltimore, for 
example, racial segregation in the 1790s occurred within the house or the lot; the property was a miniaturized plantation, and segregation was not apparent between neighborhoods (Olson, 1997). By the 1850s, Baltimore contained some alternating streets, essentially "alley habitats," or a street hierarchy such as Booth (1889/1984) mapped for London, with a certain complementarity of household labor. By the 1890s, the city possessed nodes for the "ghetto" confinement of Black families, and the ecological expression of racial segregation was shifting to the scale of wards. That pattern was generated by a process of racial turnover that can be observed at the scale of the property and the city block (Henry, 1999). By the 1950s, a radical contrast crystallized between the central city and the suburban ring, a pattern of racial segregation at the scale of the metropolis that persists into the 21st century. As Thurgood Marshall argued in his dissent to a U.S. Supreme Court decision,

In the short run, it may seem to be the easier course to allow our great metropolitan areas to be divided up each into two cities—one White, the other Black—but it is a course, I predict, our people will ultimately regret. ${ }^{18}$

The interplay of the several dimensions is well documented in studies of access to jobs, and labor markets are segmented by age and gender as well as race and wage differentials (Simkus, 1978; Blair and Lichter, 1991). Constraints on the journey to work, associated with segregated housing markets and exclusionary zoning of land, have been shown to reinforce income differentials and concentrations of poverty. The interplay is so implicated in the dynamics — what Frager (1999) calls interlocking - that policy intervention may backfire. Alternatively, the success of policy intervention may depend on a grasp of the interlocks: for example, in the Montgomery County, Maryland suburbs of Washington, DC, systematic pressure on developers to include $12-15 \%$ of housing units as "moderately priced" in every development of 50 units or more has, over the past three decades, produced desegregation along "racial" lines (Kleit, 2001; Jakobovics, 2004).

Political choices were also central to the residential ecology of the 19th-century city. The upward mobility of Irish Catholics, so impressive in Montreal, was grounded in the politics of electoral wards as well as the politics of enterprise. Dispersion of the Irish Catholic community into various wards of the city created a politics quite different from that of New York or Boston. On election days in the 1840s, the Protestant élite hired Irish Catholic laborers, plied them with rum and armed them with axehandles; by the 1860s the elections were a bit more genteel, the vote was extended to a larger middle class, and the Irish were able to cast a "swing vote" in numerous districts. On particular issues, the politics of competing dimensions of ethnicity allowed for negotiation of alliances. Catholics of both Irish and French origin united against Protestants who objected to beer and bicycle races on Sunday. The Anglophones, both Catholic and Protestant, collaborated to promote vaccination, and maligned French Canadians who violently resisted "animal" inoculation and removal of their children to a quarantine hospital (1885). In the late 1870s, negotiations among the three dominant "races" resulted in the election of several Irish Catholic mayors. Within the politics of enterprise, language influenced

\footnotetext{
${ }^{18}$ Milliken v. Bradley, 94 S. Ct. 3112 (July 25, 1974), as cited by Kluger (1975, p. 773).
} 
economic advancement. Protestant-owned firms hired English-speaking accountants, telegraphers, foremen, and railway conductors for firms with nationwide activity, imperial connections, or continental ambitions. Alternatively, French language networks assisted in preserving tight control of apprenticeship, crafts such as tanneries, and such new occupations as traveling salesmen in the circuit linking Montreal to fast-growing towns like Saint-Jérôme and Joliette.

At the highest level, the city operated as a single well-integrated economy. Agglomeration economies were centered in the downtown, and growth of the urban system as a whole generated the higher wages and profits that continued to attract migrants (Baskerville and Sager, 1998). The mosaic of ethnic communities was braided into complex chains of wholesaling-retailing and manufacturers' input-output linkages. Citizens sought to take advantage of the diversity of the city, but at the same time buffer themselves and intensify their smaller personal networks of sociability. The advantages of diversity can also be observed at a finer level in the hierarchy of streets. When rents are mapped with the detail of city blocks, it reveals a linear trace of what seemed to be "middle-rent" streets. In fact, these were business streets of considerable trade and traffic, with measurably greater internal diversity of land use, dwelling sizes, household rents, and occupations. Yet, as these streets of diversity penetrated the urban fabric, the lesser side streets, lanes, and alleys nurtured microcosms of difference.

\section{CONCLUSION}

Using a historical database within the analytical framework of a geographic information system, we mapped and measured multiple dimensions of residential segregation in Montreal in 1880 . The findings indicate that Montreal was highly segregated along lines of ethnic identity as well as socioeconomic status. At every scale of analysis, Irish Catholics showed less separation from both Protestants and French Canadians. This pattern is understandable, because they shared social spaces in the city with the French, through their common religion, and with the Protestants, through a common language. French Canadians and Protestants of British origin were more markedly segregated from each other. Ethnic difference was sharpest at the scale of the block and street. With respect to purchasing power, aggregation by ward or census division captures the extremes of "difference," while a finer aggregation, to the level of street segments, uncovers more variation. Substantial differences in occupational status emerge only at the finest-grained level of the street segment or block. Moreover, multidimensional scaling confirmed the two dimensions of ethnicity and economic status as statistically powerful. In other words, the way people shared urban space yields estimates of relative social distances between groups, and their alignments in 1880 were structured in two overriding dimensions. These are similar to prime components observed in factor analyses of 20th-century cities of North America, and even today in marketing segmentation systems such as PRIZM. ${ }^{19}$

The application of spatial and cartographic techniques demonstrates the analytical potential of GIS for interpreting the historical geography of cities. Initially, historical

\footnotetext{
${ }^{19}$ Age or "familism" is the dimension observed since the 1950s, but was less significant in 1880 because neither an elderly person nor a young adult was likely to live alone.
} 
applications of GIS were limited to map reproduction for simple display or overlays for temporal comparisons. ${ }^{20}$ Unlike students of the modern city who are restricted to aggregated data because of privacy considerations, we were able to employ micro-data on actual households to observe their residents' choices. Critical to the success of this study - and to future efforts - is the high-precision geocoding of the micro-data. Such precision and large sample size allowed us to employ an exploratory approach to data analysis-including experimentation with redistricting — so that we uncovered the multiplicity of patterns and interferences. Coupling the GIS with a statistical model, such as the classic index of dissimilarity, lends new power to grasp the scale of phenomena, to inquire into behavioral choices of 19th-century households, and even to challenge our assumptions about the meaning of "segregation" and "integration." Although we might have adopted some more analytically sophisticated measures (Wong, 2002, 2003; O'Sullivan and Wong, 2007), consistency of results supports the choice of the classic measure for our comparative purpose.

Issues of scale and boundaries are problems of universal concern in segregation analyses. The empirical observations for 1880 Montreal suggest that precision of boundaries does not have much effect on the dissimilarity index, as even arbitrary regions (a mosaic of hexagons) gave the same results as well-thought-out census divisions of similar size. On the other hand, scale had a very pronounced effect on the measures: $D$ values increased inversely with size (median area) of the spatial unit. ${ }^{21}$ These findings imply that boundary problems are a minor obstacle to comparative research, but comparisonstemporal or spatial-require control over scale of analysis. To facilitate comparative scholarly work, we suggest that future studies of spatial segregation patterns take care to report the geometry of their spatial units.

In research design, scale is apparently more important than boundary refinement, and we therefore need to ask at what scales people were "sorted." In 19th-century Montreal, the various social dimensions of diversity were "lived" at different scales. Various kinds of "separateness" were generated within a hierarchy of spaces and maintained through a variety of mechanisms. Some of our findings may well be specific to Montreal, to the social recognition of religious or linguistic difference, and to the relative sizes of the relevant population groups. They may well be specific to a particular era-the walking city, the rowhouse city, or the presence of specialized industrial zones. It is clear from this study that researchers need to explore diversity at several scales, and to discover the scale of analysis appropriate for a particular time, place, and sociospatial mosaic.

Finally, it should be acknowledged that despite the assertions of policymakers and community activists from all eras and quarters, we make no assumption here that diversity is good or segregation bad. Patterns of residential segregation, historical or contemporary, arise from both socially desirable and undesirable properties. Furthermore, factors that constrain and support choice operated at various scales. It may be that "comfort" at one scale is conducive to collaboration and tolerance of a truly urban diversity at another scale- that people move to cities to maximize opportunities (essentially

\footnotetext{
${ }^{20}$ Notable exceptions include the work of Hillier (2005), DeBats and Lethbridge (2005), and Vaughan and Penn (2006).

${ }^{21}$ Correlation between segregation values and area $(\log )$ of spatial unit is nearly perfect $\left(r^{2}=.99\right)$.
} 
agglomeration economies) at the urban scale, but seek in their personal habitats to recreate localized niches where "difference" was shared and protected.

\section{REFERENCES}

Baskerville, P., 1991, Familiar strangers: Urban families with boarders, Canada, 1901. Social Science History, Vol. 25, 321-346.

Baskerville, P. and Sager, E. W., 1998, Unwilling Idlers, the Urban Unemployed and Their Families in Late Victorian Canada. Toronto, Canada: University of Toronto Press.

Blair, S. L. and Lichter, D. T., 1991, Measuring the division of household labor: Gender segregation of household among American couples. Journal of Family Issues, Vol. 12, 81-113.

Boal, F. W., 2002, Belfast: Walls within. Political Geography, Vol. 21, 687-694.

Booth, C., 1889/1984, Charles Booth's Descriptive Map of London Poverty, 1889, 1:2500 scale. London, UK: London Topographical Society.

Bradbury, B., 1993, Working Families: Age, Gender, and Daily Survival in Industrializing Montreal. Toronto, Canada: McClelland \& Stewart.

Buck, I., 2001, The Integration Index: Using GIS to Interpret the Residential Structure of Vancouver, British Columbia. Unpublished M.A. thesis, University of Victoria, Canada.

Buck, I., Jordan, D., Mannella, S., and McCann, L., 2000, Reconstructing the geographical framework of the 1901 Census of Canada. Historical Methods, Vol. 33, 199-205.

Carey, L., 2002, Le declin de la maison de fond de cour a Montreal, 1880-1920 [The decline of rear tenements in Montreal, 1880-1920]. Urban History Review, Vol. 31, 19-36.

Carr, D., 1991, Looking at large data sets using binned data plots. In A. Buja and P. Tukey, editors, Computing Graphics in Statistics. New York, NY: Springer-Verlag, 7-39.

Carr, D. B., Olsen, A. R., and White, A., 1992, Hexagon mosaic maps for display of univariate and bivariate geographical data. Cartography and Geographic Information Systems, Vol. 19, 228-236.

Carter, H. and Wheatley, S., 1980, Residential segregation in nineteenth-century cities. Area, Vol. 12, 57-62.

Chung, S-Y. and Brown, L. A., 2007, Racial/ethnic residential sorting in spatial context: Testing the explanatory frameworks. Urban Geography, 2007, Vol. 28, 312-339.

Clark, W. A. V., 2007, Race, class, and place: Evaluating mobility outcomes for African Americans. Urban Affairs Review, Vol. 39, 667-688.

Cortese, C. F., Falk, R. F., and Cohen, J. K., 1976, Further considerations on the methodological analysis of segregation indexes. American Sociological Review, Vol. 41, 630637.

Cox, T. F. and Cox, M. A. A., 1994, Multidimensional Scaling. London, UK: Chapman \& Hall.

Curtis, B., 2000, The Politics of Population, State Formation, Statistics and the Census of Canada, 1840-1875. Toronto, Canada: University of Toronto Press. 
Darroch, A. G. and Ornstein, M. D., 1980, Ethnicity and occupational structure in Canada in 1871: The vertical mosaic in historical perspective. Canadian Historical Review, Vol. 61, 303-333.

Darroch, G. and Ornstein, M. D., 1984, Ethnicity and class, transitions over a decade: Ontario, 1861-1971. Historical Papers, Vol. 1984, 111-137.

DeBats, D. A. and Lethbridge, M., 2005, GIS and the city: Nineteenth-century residential patterns. Historical Geography, Vol. 33, 78-98.

Dennis, R., 1984, English Industrial Cities of the Nineteenth Century, A Social Geography. Cambridge, UK: Cambridge University Press.

Dufaux, F., 2000, A new world from two old ones: The evolution of Montreal's tenements, 1850-1892. Urban Morphology, Vol. 4, 9-19.

Duncan, O. D. and Duncan, B., 1955, A methodological analysis of segregation indexes. American Sociological Review, Vol. 20, 210-217.

Frager, R. A., 1999, Labour history and the interlocking hierarchies of class, ethnicity, and gender: A Canadian perspective. International Review of Social History, Vol. 44, 217-247.

Gilliland, J., 1998, Modeling residential mobility in Montreal, 1860-1900. Historical Methods, Vol. 31, 27-42.

Gilliland, J., 2004, Muddy shore to modern port: The redimensioning of Montreal's waterfront time-space. Canadian Geographer, Vol. 48, 448-472.

Gilliland, J. and Olson, S., 1998, Claims on housing space in nineteenth-century Montreal. Urban History Review, Vol. 26, 3-16.

Gilliland, J. and Olson, S., 2003, Montréal, l'avenir du passé [Montreal: The future of the past]. GÉOinfo, Vol.18, 5-7.

Goad, C. E., 1881, Atlas of the City of Montreal: From Special Survey and Official Plans, Showing All Buildings \& Names of Owners, Montreal, Canada: Author.

Goheen, P. G., 1970, Victorian Toronto 1850-1900. Chicago, IL: University of Chicago, Department of Geography.

Greenberg, A., 1999, Irish in the city: Recent developments in American urban history. Cambridge Historical Journal, Vol. 42, 571-581.

Greenberg, S. W., 1981, Industrial location and ethnic residential patterns in an industrializing city. In T. Hershberg, editor, Philadelphia: Work, Space, Family and Group Experience in the Nineteenth Century. New York, NY: Oxford University Press, 204232.

Gregory, I. N. and Healey, R. G., 2007, Historical GIS: Structuring, mapping and analyzing geographies of the past. Progress in Human Geography, Vol. 31, 638-653.

Gregory, I. N., Kemp, K., and Moster, R., 2001, Geographical information and historical research: Current progress and future directions. History and Computing, Vol. 13, $7-$ 21.

Hanna, D., 1986, Montreal, A City Built by Small Builders, 1866-1870. Unpublished Ph.D. thesis, Department of Geography, McGill University.

Hanna, D. and Olson, S., 1983, Métiers, loyers et bouts de rues: L'armature de la société montréalaise, 1881 à 1901 [Occupations, rents, and street-segments: The reinforcement of Montreal social structure, 1881 and 1901]. Cahiers de Géographie du Québec, Vol. 27, 255-275. 
Hanna, D. and Olson, S., 1990, The social landscape of Montreal, 1901. In D. Kerr and D. W. Holdsworth, editors, Historical Atlas of Canada, Volume III. Toronto, Canada: University of Toronto Press, Plate 30.

Harris, R., 1992, The end justified the means: Boarding and rooming in a city of homes, 1891-1951. Journal of Social History, Vol. 26, 331-358.

Henry, K. A., 1999, Incorporating the Temporal Component in GIS: The Spatial-Temporal Evolution of a Baltimore City Block, 1850-1920. Unpublished master's thesis, Towson University, Maryland.

Hiebert, D., 1991, Class, ethnicity and residential structure: The social geography of Winnipeg, 1901-21. Journal of Historical Geography, Vol. 17, 56-86.

Hillier, A., 2005, Residential security maps and neighborhood appraisals. The Homeowners' Loan Corporation and the case of Philadelphia. Social Science History, Vol. 29, 207-233.

Hoskins, R. F. H., 1989, An analysis of the payrolls of the Point St. Charles Shops of the Grand Trunk Railway. Cahiers de Géographie du Québec, Vol. 33, 323-344.

Jakabovics, A., 2004, Building Equity: The Evolution and Efficacy of Montgomery County's Moderately Priced Dwelling Unit Legislation. Unpublished M.C.P. thesis, Massachusetts Institute of Technology, Department of Urban Studies and Planning.

Jakubs, J. F., 1981, A distance-based segregation index. Journal of Socio-Economic Planning Sciences, Vol. 15, 129-141.

Johnston, R. J., 1976, Residential area characteristics: Research methods for identifying urban sub-areas. In D. T. Herbert and R. J. Johnston, editors, Social Areas in Cities. London, UK: Wiley, 193-235.

Johnston, R. J., Poulsen, M., and Forrest, J., 2007, The geography of ethnic residential segregation: A comparative study of five countries. Annals of the Association of American Geographers, Vol. 97, 713-738.

Jones, E., 1965, A Social Geography of Belfast. London, UK: Oxford Press.

Kleit, R. G., 2001, The role of neighborhood social networks in scattered-site public housing residents' search for jobs. Housing Policy Debate, Vol. 12, 541-573.

Kluger, R., 1975, Simple Justice. New York, NY: Vintage.

Knowles, A. K., 2002, Past Time, Past Place: GIS for History. Redlands, CA: ESRI Press.

Knowles, A. K., 2005, Emerging trends in historical GIS. Historical Geography, Vol. 33, 7-13.

Kok, J., Mandemakers, K., and Wals, H., 2005, City nomads: Changing residence as a coping strategy, Amsterdam, 1890-1940. Social Science History, Vol. 29, 15-43.

Kruskal, J. B. and Wish, M., 1978, Multidimensional Scaling. London, UK: Sage.

Lawton, R. and Pooley, C. G., 1976, The Social Geography of Merseyside in the Nineteenth Century. Liverpool, UK: Final report to SSRC.

Lewis, R., 1991, Class residential patterns and the development of industrial districts in Montreal, 1861 and 1901. Journal of Urban History, Vol. 17, 123-152.

Lewis, R., 2000, Manufacturing in Montreal: The Making of an Industrial Landscape, 1850 to 1930. Baltimore, MD: Johns Hopkins University Press.

MacLeod, R., 2003, The road to Terrace Bank: Land capitalization, public space, and the Redpath family home, 1837-1861. Journal of the Canadian Historical Association, Vol. 14, 165-192. 
MacLeod, R. and Poutanen, M. A., 2004, A Meeting of the People, School Boards and Protestant Communities in Quebec, 1801-1998. Montreal, Canada: McGill-Queen's University Press.

Massey, D. S. and Denton, N. A., 1988, The dimensions of residential segregation. Social Forces, Vol. 67, 281-315.

Morgan, B. S., 1983, An alternative approach to the development of a distance-based measure of racial segregation. American Journal of Sociology, Vol. 88, 1237-1249.

Morrill, R. L., 1991, On the measure of geographical segregation. Geography Research Forum, Vol. 11, 25-36.

Olson, S., 1997, Baltimore: The Building of an American City. Baltimore, MD: Johns Hopkins University Press.

Olson, S., 2000, Feathering her nest in nineteenth-century Montreal. Social History/ Histoire Sociale, Vol. 33, 1-35.

Olson, S. and Thornton, P., 2001, La croissance naturelle des Montréalais au XIXe siècle [Natural growth of Montrealers in the nineteenth century]. Cahiers Québécois de Démographie, Vol. 30, No. 2, 7-46.

Olson, S. and Thornton, P., 2002, The challenge of the Irish Catholic community in nineteenth-century Montreal. Social History/Histoire Sociale, Vol. 35, 331-362.

Openshaw, S., 1984, The Modifiable Areal Unit Problem. Norwich, UK: Geo Books.

O’Sullivan, D. and Wong, D. W., 2007, A surface-based approach to measuring spatial segregation. Geographical Analysis, Vol. 39, 147-168.

Park, R. E., Burgess, E. W., and McKenzie, R. D., 1925, The City. Chicago, IL: University of Chicago Press.

Parr, J., 1994, Labouring Children: British Immigrant Apprentices to Canada, 18691924. Toronto, Canada: University of Toronto Press.

Pooley, C. G., 1977, The residential segregation of migrant communities in mid-Victorian Liverpool. Transactions of the Institute of British Geographers, Vol. 2, 364-382.

Pooley, C. G., 1984, Residential differentiation in Victorian cities: A reassessment. Transactions, Institute of British Geographers, Vol. 9, 131-144.

Pratt, E. E., 1911, Industrial Causes of Congestion of Population in New York City. New York, NY: Columbia University Press.

Robert, J-C., 1994, Atlas historique de Montréal [Historical Atlas of Montreal]. Montréal, Canada: Septentrion.

Robinson, W. S., 1950, Ecological correlations and the behavior of individuals. American Sociological Review, Vol. 15, 351-357.

Senior, H., 1972, Orangeism: The Canadian Phase. Toronto, Canada: McGraw-Hill Ryerson.

Simkus, A. A., 1978, Residential segregation by occupation and race in ten urbanized areas, 1950-1970. American Sociological Review, Vol. 43, 81-93.

Sims, M., 1999, High-status residential segregation among racial and ethnic groups in five metro areas, 1980-1990. Social Science Quarterly, Vol. 80, 556-573.

Stata Release 9, 2005, Multivariate Statistics Reference Manual. College Station, TX: Stata Press.

Stouffer, S. A., 1949, The American Soldier. Princeton, NJ: Princeton University Press.

Sweeny, R. C. H. and Olson, S., 2003, MAP: Montréal l'avenir du passé: Sharing geodatabases yesterday, today and tomorrow. Geomatica, Vol. 57, 145-154. 
Thornton, P. and Olson, S., 1997, Infant vulnerability in thee cultural settings in Montreal 1880. In A. Bideau, B. Desjardins, and H. Perez-Brignoli, editors, Infant and Child Mortality in the Past. Oxford, UK: Clarendon Press, 216-241.

Trigger, R., 2001, The geopolitics of the Irish-Catholic parish in nineteenth-century Montreal. Journal of Historical Geography, Vol. 27, 553-572.

Trigger, R., 2002, Protestant restructuring in the Canadian city: Church and mission in the industrial working-class district of Griffintown Montreal. Urban History Review, Vol. 31, 5-18.

Van Valey, T. L. and Roof, W. C., 1976, Measuring residential segregation in American cities: Problems of intercity comparison. Urban Affairs Quarterly, Vol. 11, 453-468.

Vaughan, L. and Penn, A., 2006, Jewish immigrant settlement patterns in Manchester and Leeds, 1881. Urban Studies, Vol. 43, 653-671.

Walks, R. A. and Bourne, L. S., 2006, Ghettos in Canada's cities? Racial segregation, ethnic enclaves, and poverty concentration in Canadian urban areas. Canadian Geographer, Vol. 50, 273-297.

Ward, D., 1975, Victorian cities: How modern? Journal of Historical Geography, Vol. 1, 135-151.

Ward, D., 1980, Environs and neighbours in the "Two Nations": Residential differentiation in mid-nineteenth century Leeds. Journal of Historical Geography, Vol. 6, 133162.

Warner, S. B., 1968, The Private City: Philadelphia in Three Periods of Its Growth. Philadelphia, PA: University of Pennsylvania Press.

White, M. J., 1986, Segregation and diversity measures in population distribution. Рориlation Index, Vol. 52, 198-221.

Wirth, L., 1928, The Ghetto. Chicago, IL: University of Chicago Press.

Wong, D. W. S., 1993, Spatial indices of segregation. Urban Studies, Vol. 30, 559-572.

Wong, D. W. S., 1997, Spatial dependency of segregation indices. The Canadian Geographer, Vol. 41, 128-136.

Wong, D. W. S., 2002, Modeling local segregation: A spatial interaction approach. Geographical and Environmental Modelling, Vol. 6, 81-97.

Wong, D. W. S., 2003, Implementing spatial segregation measures in GIS. Computers, Environment and Urban Systems, Vol. 27, 53-70.

Wong, D. W. S., Lasus, H., and Falk, R. F., 1999, Exploring the variability of segregation index D with scale and zonal systems: An analysis of thirty U.S. cities. Environment and Planning A, Vol. 31, 507-522.

Wong, D. W. S., Reibel, M., and Dawkins, C. J., 2007, Introduction-Segregation and neighborhood change: Where are we after more than a half-century of formal analysis. Urban Geography, Vol. 28, 305-311.

Zunz, O., 1982, The Changing Face of Inequality: Urbanization, Industrialization and Immigrants in Detroit, 1880-1920. Chicago, IL: University of Chicago Press. 